\title{
(Des)Silêncios
}

Daniel Conte ${ }^{1}$

Resumen: El texto busca evidenciar las relaciones imaginéticas existentes entre Portugal, Brasil y Angola, apoyándose en las narrativas de Pepetela: Lueji, o nascimento dum império y A geração da utopia. Pretende dialogar con eventos históricos que evidencian las relaciones entre Brasil, África y Portugal y demostrar que existen marcas significativas entre los imaginarios de esas naciones.

Palabras-clave: África, Portugal, Brasil, Literatura, Pepetela.

Resumo: O texto busca evidenciar as relações imagéticas existentes entre Portugal, Brasil e Angola, apoiando-se nas narrativas de Pepetela: Lueji, o nascimento dum império e A geração da utopia. Pretende dialogar com eventos históricos que evidenciam as relações entre Brasil, África e Portugal e mostrar que existem marcas significativas entre os imaginários dessas nações. Palavras-chave: África, Portugal, Brasil, Literatura, Pepetela.

\section{O caminho}

É pouco provável que pensemos, atualmente, a organização imaginário-representativa dos países colonizados/colonizadores desde um aspecto de "(im)pureza cultural", isso nos conduziria à redutora bipolaridade "origem/cópia" e relegaria à insignificância empreendimentos significativos que fizeram parte do processo emancipatório das literaturas das ex-colônias de Portugal. A ideia de considerar a permeabilidade do Outro nas representações da identidade nacional é já comum àqueles que se propõem olhar a escritura literária como produto de embates significativos entre o sujeito social e os procedimentos que o colocam na condição de redizer-se sistemicamente para, em verdade, renovar-se e fazer, ainda, respirar a própria ossatura representativa em que se inserem. Portanto é natural que, em nosso caso, ao considerar as literaturas da África lusófona como "paradigmáticas" desse [re]enunciar, direcionemos nosso olhar de modo a vê-las como resultado de uma marcha emancipatória - antes sussurrada, e organizadamente iniciada com as independências, vindo até a atualidade. 
É nesse sentido que temos de pensar o caminho simbólico constituidor das nações da África lusófona, representado também na malha ficcional, uma vez que o pós-independência favoreceu a erosão das fronteiras rigidamente demarcadas pela imposição político-imagética do colonialismo.

A necessidade de redizer a oficialidade da História que se lhe foi à África imposta, encontra nas Artes e na Literatura um campo profícuo de ação e de possibilidade de assunção do sujeito colonizado, antes relegado a uma violenta condição silenciante. Esse fazer literário está muito próximo de nós, de nossa cultura, de nossa religiosidade e de nossa produção literária - principalmente do nosso Regionalismo, a partir dos anos 40. É um caminho pensado em nível simbólico e prático. Uma edificação referencial de Nações emergentes que se erguem depois de séculos de um sistema colonialista devastador.

A literatura da África colonizada, dessa forma, é uma escritura que exerceu uma tarefa fundamental para a organização de uma sociedade que se sonhou mais justa, solidária e fraterna e que, sob a égide da igualdade, conquistou sua liberdade - alheia, em tempos, à rede simbólica que lhe foi imposta durante os anos de gesta colonial. A literatura, aí, teve o papel de organizar os anseios dos cidadãos dos novos Estados de Direito, de repensar a tradição e de apontar, ainda, o caminho experimental do socialismo com valores, agora, permeados pela sensação de estarem os africanos libertos, em parte, dos mecanismos colonialistas.

Já nas primeiras décadas do século XX, estendendo-se aos anos que seguem, a produção literária africana vai elevar o negro a um patamar de audibilidade dentro do fazimento produtivo de uma literatura de cunho marxista. Escritores como Pepetela, Agostinho Neto, José Luandino Vieira, Manuel Ferreira, Orlando Mendes, entre outros, vão, através de suas obras, denunciar não só as contradições do sistema colonial, mas fazer com que a imagem do negro migre do silêncio histórico à habitação do signo da revolução.

Essa literatura é já influenciada pelo neo-realismo português e pelo romance social do Brasil e erguerá a voz contra as injustiças da máquina social. Laranjeira (2001, p. 38) observa que esta proximidade entre as literaturas brasileira e luso-africana, deu-se por um lado, pela "quantidade e variedade de obras"; por outro, pela "continuidade de produção ao longo das décadas, sobretudo a partir dos anos 30 deste século". É a partir da solidificação desse dialogismo político/estético entre os escritores que perceberemos as influências literárias que se vão intensificar ao longo dos anos que seguem até as independências.

Pepetela está entre os escritores que leram a literatura brasileira, antes mesmo de engendrar sua atuação seja como quadro orgânico do MPLA, seja como agente do Ministério da Educação em Angola. Em entrevista a Carlos Brazil e Guilherme Azevedo, quando perguntado em que o Brasil lhe tinha influenciado, responde:

Parte da família da minha mãe veio do Brasil para Angola em meados do século XIX. Portanto, o Brasil sempre fez parte da família e muito novo tive contacto com a sua literatura e música, através delas chegando à alma brasileira. Na tradição da minha família havia comidas que hoje sei serem de origem brasileira. E quanto às influências, fatalmente quem começa a ler Jorge Amado e José Lins do Rego com 13 anos de idade tem de ter sido influenciado por essa literatura. Pouco mais tarde, Graciliano [Ramos] e Érico Veríssimo. Será difícil distinguir o que o Brasil moldou na minha sensibilidade, pois a própria sensibilidade brasileira já tinha sido influenciada pela africana, angolana em particular. Mas digamos que o facto de essa literatura mostrar realidades sociais, por exemplo do nordeste, muito próximas das que eu vivia em Benguela, exactamente na mesma latitude de Salvador da Bahia, levou-me a ser mais sensível às injustiças que via todos os dias e a querer lutar contra elas, o que comecei a fazer com 17 anos de idade de forma consciente. 
As palavras do escritor são contundentes e evidenciam a imaterialidade das relações do imaginário, das significações conceituais de colonizador/colonizado, do ser brasileiro, africano ou português e dos elementos referenciais que estruturam as condições de produção dos discursos nacionais. Não existe, para Pepetela, uma precisão da influência constitutiva daqueles sujeitos que habitaram o espaço colonial, isso é não mensurável. Mas uma coisa afirma, categoricamente: "quem começa a ler Jorge Amado e José Lins do Rego com 13 anos de idade tem de ter sido influenciado por essa literatura".

\section{A resistência e a literatura}

A fase da resistência anticolonial organizada se desenha nos anos 60 com o início das Guerras de Libertação, e o período pós-independências é o momento em que a literatura sofre violentas mudanças, como violentas são as modificações da ossatura social. Rita Chaves (2010, p.14) vai observar que surge, então, "a elevação de uma nova mitologia, capaz de fazer frente aos deuses eleitos pela gesta colonial, [indicando] a necessidade de uma apropriação da história”. Apropriar-se de sua História é, para o sujeito, empoderar-se dos elementos que o estruturaram como indivíduo e, a partir de então, lançar-se à tarefa de ressignificação dos signos ideológicos que o compõem, numa espécie de decantação dos estratos simbólicos que, de fato, significam. Esse movimento é relevante quando pensamos no enleio cultural que vem à tona. E é nessa complexidade, nesse novelo ideológico, que podemos considerar representação de uma rede imaginária lusófona que envolve Brasil, Portugal e Angola no período em que inicia a guerra de resistência à colonização portuguesa no país africano e, com ela, uma profícua produção literária, indo até o pós-independência.

Emerge desse contexto das representações culturais uma funcionalidade imagética que comportará o mosaico lusófono trazido desde uma tradição político-cultural e de seus movimentos de sentido até uma sedimentação efetiva do constructo de suas influências. Lançando um olhar atento às obras de Pepetela, uma das vozes mais expressivas da África contemporânea, notamos a relação dialógica da rede simbólica e a construção de uma organização imagética significante. $\mathrm{O}$ autor sempre teve um olhar crítico sobre as relações históricas entre Portugal e suas colônias, especialmente ao liame que envolve Angola e Brasil. É crítico em relação ao conceito de lusofonia e perspicaz quando percebe a herança colonial:

A lusofonia é um mito forjado há pouco e que não vai ter grandes frutos se se continuar em insistir que o que nos une é só a língua. Os países estão cada vez mais integrados em organizações regionais e essa integração é mais forte em interesses que os discursos sobre a amizade de países de língua comum. Acredito que na área da cultura podemos avançar mais na aproximação, se os governos derem às sociedades os meios para o fazerem. Fora da área da cultura, vejo pouco. Os negócios fazem-se preferentemente em inglês. A dita lusofonia servirá para umas viagens e reuniões dos dirigentes, pouco mais. (BRAZIL \& AZEVEDO: 2012).

O olhar acentuado de Pepetela mostra uma crítica à política entre os países lusófonos, trazendo à tona um colonialismo simbólico. Colonialismo que favorece ações que priorizam o comércio e relegam os mecanismos culturais a um plano de desinstrumentalização.

Em suas narrativas, o Brasil é norteador de reações e de movimentos de sentidos, uma vez que, no processo de constituição das identidades nacionais emergentes da África lusitana, dialogicamente, Portugal e Brasil aparecem como vetores de verticalização das imagens de nação, trazendo possibilidades de negação/reconhecimento constituintes do sentido sócio-organizacional. 
Em tal relação, contrapondo-se à imagem colonizadora de Portugal, o Brasil habitará a História de Angola numa ação desnudante e rompedora do silenciamento patrocinado pela oficialidade histórica, fazendo com que emerja uma possiblidade outra de diálogo entre os dois discursos: o ficcional e o histórico. A análise das tessituras literárias, através de uma aproximação comparativa das formações discursivas, faz com que se possam sistematizar as influências culturais, a gesta de imagens comuns às nações lusófonas componentes deste imaginário e suas repercussões efetivas dentro das práticas culturais portuguesas, brasileiras e africanas, evidenciando em Angola o surgimento e a solidificação de um conceito de nação com acentuado hibridismo cultural, conforme Stuart Hall (1999), e com fronteiras imagéticas tênues e permeáveis, quando trazemos à discussão Homi Bhabha (2007). Ou, ainda, como afirma Maria Manuela Tavares Ribeiro (2002, p. 387), dito "por outras palavras, europeus de primeira hora, os portugueses eram intercontinentais já que a nossa língua e a nossa cultura criaram raízes na África, no Brasil, no oriente". Nessa relação de dizeres - Brasil, Portugal e Angola - aproximados pela história de suas políticas e de suas literaturas, servem de exemplo para o que aponta Benjamin Abdala Júnior, ao ensinar que quando

comparamos literaturas de um mesmo sistema linguístico, modelos semelhantes de articulação literária tendem a ser utilizados com maior frequência pelas similaridades dos discursos ideológicos e de outras séries culturais. Ao mesmo tempo, a atualização específica de cada país pode facilmente passar para outro, como criações intercambiáveis, se não implicar dependência cultural. Pela proximidade da situação comunicativa, conforme temos desenvolvido, a tendência é africanos lusófonos, brasileiros e portugueses trabalharem literariamente modelos geradores equivalentes, com “estratégias” discursivas igualmente confluentes (ABDALA JUNIOR, 2007, p. 65).

O que evidencia o Abdala é uma constante dentro da organização sistêmica das literaturas de língua portuguesa: as similaridades de discursos, gestados a partir de compêndios imagéticos idiossincráticos, criam um novelo ideológico complexo e gestor de configurações significantes, e com maior latência a partir da segunda metade do século XX. É nesse momento importante de contestação do processo colonial que "a imagem do Brasil, em matizes multiplicados iria pesar positivamente na construção de uma identidade cultural comprometida com a libertação" (CHAVES, 2006, p. 34). O mosaico de significações mostrará que o Eu e o Outro, formadores do imaginário lusófono, vão encontrar-se em imagens comuns de uma funcionalidade que iniciou com a colonização portuguesa no Brasil e na África. Tais aproximações imagéticas se traduzem na matéria prima da literatura dos países lusófonos que comportam em seus imaginários relações de acercamentos produtoras de sentido, embora sejam sentidos, por vezes, que denotem oposições ideológicas.

Quando lançamos um olhar sobre a produção de Pepetela, começamos a compreender sua cartografia imagética e seu esforço em "descobrir" a terra e (re)fundar literariamente seu país. É imprescindível, para tanto, ter em vista as "revoluções" que, a partir da década de 50, pairam sobre a África, especialmente, sobre Angola. Há um sentimento nacionalista de maior intensidade do que qualquer anterior manifestação. Sentimento que foi resultado da observação e da análise da trajetória histórica de mais de cinco séculos de colonialismo português e das reações sociais de outras nações colonizadas, em função da prática colonialista que havia se esgotado historicamente. Pepetela viveu essa intensa manifestação em todas suas nuances: foi numa região fronteiriça do velho reino de Benguela 
que Pepetela nasceu, justamente no limite, onde terminava a cidade branca e iniciava um emaranhado de necessidades criadas pela desorganização colonialista, que denominavam os africanos de Musseque (originalmente terra vermelha, mais tarde os bairros periféricos e pobres de Luanda, as favelas). O autor é constructo, como é a própria cultura angolana, de uma hibridização da base africana civilizacional e da influência euro-ocidental, a portuguesa. E é a partir deste local que propõe, através de sua obra, um posicionamento crítico referente à História angolana e de sua colonização, podendo-se afirmar que o autor procura uma releitura efetiva de sua condição de sujeito dizente; com uma visão não apenas do ponto de vista da colonização, da oficialidade, mas do espaço íntimo do angolano, dando a escutar a voz daquelas populações que viveram a História de fato, longe de uma verticalização nacionalista.

Nesse sentido, o autor introduz ao aspecto historiográfico africano uma questão importante: a "da ampliação da audiência do historiador profissional, de permitir um acesso mais amplo à história de um padrão profissional do que aquele normalmente permitido pelos nobres acadêmicos profissionais e seus alunos" (SHARPE, 1992, p. 55), trazendo as possibilidades ressignificadoras. Sharpe (1992, p. 54) observa que isso cumpre duas importantes tarefas:

A primeira é servir como um corretivo à história da elite [...] A Segunda é que, oferecendo esta abordagem alternativa, a história vista de baixo, abre a possibilidade de uma síntese mais rica da compreensão histórica, de uma fusão da história da experiência do cotidiano das pessoas com a temática dos tipos mais tradicionais da história. Inversamente, poderia ser argumentado que a temática da história vista de baixo, os problemas de sua documentação e, possivelmente, a orientação política de muitos de seus profissionais criam um tipo distinto de história.

É possível apropriarmo-nos desse estudo e ressignificá-lo, inserido nas condições de produção das literaturas lusófonas, dando às imagens gestadas por sua discursividade não uma simples transposição semântica de tais imagens, mas sim uma consistente funcionalidade aos símbolos que as compõem em seus aspectos formais e de conteúdo, suportados pela História que lhes é comum. Tal análise se torna plausível, uma vez que a relação do homem com a História se constrói em seus embates diários ao largo dos anos e sempre haverá uma voz homogeneizante a ser contestada e um discurso totalizador a ser redito por aqueles que o "sofreram".

As diversas produções literárias dessa rede lusófona são entrelaçadas por suas "atualizações nacionais" eliminando o caráter de dívida entre as literaturas, dando às articulações uma autonomia ideológica, sem perder de vista, obviamente, o caráter interimagético, valorizando as releituras do macrossistema literário, pois "o imaginário recria e reordena a realidade, encontra-se no campo da interpretação e da representação, do real" (LAPLANTINE \& TRINDADE, 1997, p. 79). A contraponto da razão canônica colonialista, a literatura de Pepetela traz os mitos e suas nuances como um elemento vivo para o africano e seu pragmatismo aparece como uma espécie de justificativa ideológica, evidenciando o estado condicionante do imaginário e condicionado do Homem. No pensamento do historiador Joseph Ki-Zerbo (1972), a procura da identidade para os africanos faz-se pela reunião dos elementos dispersos na memória coletiva e pelo silêncio primevo que põe homens e mulheres em contato com o espaço sacro, possibilitando a constituição de um espaço para o devaneio. 
Os princípios que fazem parte do campo de representações não se mostram como mera transposição imagética, e sim como uma conceituação histórico-literária. Os elementos culturais produtores de sentido da identidade primeira africana, os mitos, influenciam e são influenciados pela diaspórica relação dos signos angolanos, brasileiros e portugueses e de suas significações convergentes. Manuel Alegre (1995, p. 3-4) registra a importância de um escritor como Pepetela, diz que o autor "não é só o maior romancista da África que se exprime literariamente em português. Ele é o escritor da língua portuguesa que mais intensamente e melhor do que nenhum outro, fixou nos seus livros o itinerário e o perfil de uma geração", seus personagens são ícones de uma ossatura social em evidência. São microssistemas que representam o espaço e a História de Angola e, em menor grau representativo, do Brasil e de Portugal. Transitam estes personagens desde a organização do Império Lunda, em Lueji, o nascimento dum império (1989), negando o colonizador e buscando no engendramento de novos signos culturais a síntese da formação da nação angolana. Além de elevar à compreensão do leitor o intento dos brasileiros que buscam na espiritualidade angolana as referências necessárias para o entendimento de sua condição mestiça.

A senda vai até o desencanto do pós-revolução em A Geração da Utopia (1992) com as matizes portuguesas geradoras do desprestígio da prática colonialista, uma vez que o "processo de aculturação do colonialismo português visava à desculturação dos outros povos. Se Portugal impôs seus padrões, também foi marcado, por sua vez, pelo sistema que estabeleceu ao voltar-se obsessivamente para o sonho do "ultramar" (ABDALA JUNIOR, 2007, p. 37).

Estes arquétipos estabelecem uma organização e funcionalidade da resistência e repensagem que produzem uma guerra civil silenciosa com a corrupção e que transgridem as tradições e que condenam e geram a desolação e o deslocamento. Pepetela é um escritor que relê processual e continuamente sua condição de sujeito histórico, elevando o regional, aquilo que alimenta a aridez das gargantas secas de grito e sede, a um patamar da universalidade condizente à sua existência. É muito pouco provável que se encontre em outro escritor de África um panorama tão amplo, tão pleno e tão falável da História de uma nação e das imagens que o compõem em relação com o outro que comporta os movimentos das influências.

Desde essas condições de produção, surge a feitura de uma narrativa sedimentada em um alicerce intercultural, referencializando-se, gestando um leitor já permeado de anseios plenos. Faz, ainda, o que Barthes (1985) ensina n'O discurso da História: eleva sua literatura a uma possibilidade de leitura a mais, como fonte documental para os historiadores. Nesta perspectiva, as obras Lueji, o nascimeno dum império e A geração da utopia têm uma significância condizente, porque ao largo da malha narrativa seus personagens se referem a um Brasil que oferece elementos compósitos da organização imagética e do rearranjo simbólico da identidade Nacional, que devido aos sucessivos movimentos beligerantes para a libertação, está reordenando-se; importante que se diga, ressignificando-se, refazendo-se em mosaico múltiplo.

É relevante, ainda, dizer que, de acordo com a professora Rita Chaves (2006, p. 33), desde

o século XIX, mas, sobretudo, a partir dos anos 1940, os escritores africanos nos territórios ocupados por Portugal alimentam com a literatura brasileira um vivo processo de interlocução, que ganha vitalidade quando se reforçam os projetos de construção de identidade nacional, fenômeno que se estende pelo período das lutas que antecederam a libertação de países como Angola, Cabo Verde e Moçambique. Antônio Jacinto, Mário Antônio, Luandino Vieira, José Craveirinha, Gabriel Mariano, [Pepetela], entre outros autores empenhados na formulação de novos modelos 
culturais que servissem de base para o debate sobre a libertação, vão encontrar na obra de Jorge Amado, Graciliano Ramos, Rachel de Queirós, José Lins do Rego, por exemplo, uma fonte de inspiração para as propostas que pretendiam desenvolver, [...]

Assim, contrapondo-se aos modelos impostos por Portugal que tentava, ainda, perpetuar-se culturalmente nas colônias, impondo uma política-cultural em exaustão semântica. Chaves ainda observa que era nos textos brasileiros que iam buscar elementos capazes de refletir novas formas de ver o mundo. Desta relação surgem personagens leitores na tessitura textual que, ao lerem, leem o Brasil e leem Portugal, porque invocam uma malha de imagens fazedora dos países e de suas literaturas.

N'A geração da utopia, o ponto de contato se dá pela literatura, pelo reconhecer-se na linguagem daquele que sofreu um processo semelhante de colonização; o Outro distante geograficamente, em verdade, é um alheio-próximo que se acerca pela via cultural mais importante: a língua e sua configuração sígnica.

- Vê o livro do Viriato da Cruz. Ele marca a ruptura definitiva com a literatura portuguesa. Utilização da voz do povo. Na língua que o povo de Luanda usa. Já não tem nada a ver com tudo o anterior. Em particular com os portugueses. A literatura à frente, a expressar o sentimento popular, de diferença. Os brasileiros fizeram isso há trinta anos (PEPETELA, 1992, p.65).

O angolano que marca a ruptura com os padrões estéticos metropolitanos e valoriza a manifestação do popular, está amparado pela literatura brasileira; segundo o personagem, é o Brasil que legitima o processo de ruptura. É pertinente registrar que foram africanos os primeiros países a reconhecer a independência do Brasil no século XIX. Foi no dia 4 de dezembro de 1824, que passou pelo Rio de Janeiro, a fim de comunicar a Dom Pedro I, o reconhecimento da independência do Brasil, o imperador do Beni e rei de Ajan, vassalo do Obá do Benin. Essa ação diplomática não se dá à revelia, porque "Missões dos Reis de Abomé, de Onim e de Porto Novo tinham sido frequentes durante o período colonial, pois era por meio da Bahia que o governo português mantinha o grosso de suas relações não apenas com os estados africanos, mas também com Angola", como nos explica Alberto da Costa e Silva (2003, p. 8). Naquela nação, as

relações diretas com o Brasil eram tradicionalmente mais intensas do que as com a metrópole portuguesa, a notícia do 7 de setembro de 1822 teve forte impacto e consequências imediatas. Surgiu, desde logo, em Benguela, uma corrente política favorável à união daquele território ao Brasil. E, dos três deputados angolanos eleitos para as cortes gerais portuguesas, dois, na viagem para Lisboa, aderiram à causa da independência brasileira e ficaram no Brasil: Euzébio de Queirós Coutinho Matoso Câmara e Fernando Martins do Amaral Gurgel e Silva. O terceiro só seguiu para Portugal depois de muito hesitar.

A atitude dos deputados foi de repercussão tal que gerou uma divisão entre os partidos políticos e a opinião pública. Portugal, receoso de que houvesse uma junção entre os territórios brasileiros e angolanos, o que abalaria econômica e socialmente a metrópole e a tornaria insustentável, tranquilizou-se somente à assinatura do Tratado de Reconhecimento da Independência do Brasil, com a mediação da Inglaterra no dia 29 de agosto de 1825 . Essa relação se estenderá no imaginário africano e pautará muito da produção 


\section{Conexão Letras}

literária desde os anos 1940, como afirmamos antes. E Pepetela deixa isso evidente em sua literatura: n'A Geração da Utopia, num exercício crítico aos portugueses [e ao intento da imposição de parâmetros literários], Horácio, o mesmo personagem que atribui à produção literária brasileira o movimento de "voltar-se" para o popular, valorizando a linguagem do povo, em tom conceitual, fala aos amigos:

Qual Camões, qual Pessoa, Drummond é que era, tudo estava nele, até a situação de Angola se podia inferir na sua poesia. Por isso vos digo, os portugueses passam a vida a querer-nos impingir a sua poesia, temos de a estudar na escola e escondem-nos os brasileiros, nossos irmãos, poetas e prosadores sublimes, relatando os nossos problemas e numa linguagem bem mais próxima da que falamos nas cidades. Quem não leu Drummond é um analfabeto (PEPETELA, 1992, p. 31).

É bastante significativa no excerto, a referência ao poeta brasileiro como o norte de leitura da poesia do sujeito angolano e da negação de Camões e Pessoa, do distanciamento de sua linguagem, da abissal diferença imagética - frustrado intento de colonialismo estético. Como ensina Bachelard (1998, p. 4) "pede-se ao leitor de poemas que não encare a imagem como um objeto, muito menos como um substituto ao objeto, mas que capte sua realidade específica. Para isso é necessário associar sistematicamente o ato da consciência criadora ao produto mais fugaz da consciência: a imagem poética”. Assim o faz Horácio, aproxima realidades complementares de signos entrelaçados e as decanta a um processo imagético associativo/dissociativo, levando em consideração não só a consciência criadora, mas a imagem gestada por ela. A reação do dizente angolano é o alicerce daquilo que se desenha naturalmente na História: a sedimentação do oceano como via de acesso depois do proferimento da palavra e a filiação às imagens que se coadunam historicamente no campo das representações sociais. O oceano virou ponte depois que a leitura da poesia imagem significativa do outro em sua representação íntima - se ergueu funcionalmente no emaranhado dos processos históricos, obtendo a estranha "arquipotência sagrada ao ser proferida", como aponta Cassirer (1975).

Em meio ao intento de segurar-se na condição de último grande império, Portugal, nessa rede significativa, evidencia outro código - submerso à cristalização homogeneizante do discurso histórico - o da rede de influências, o da crioulização, pois sabe-se que

\footnotetext{
esse país sempre se voltou para o mar, para as ex-colônias. Mais para atividades fora do continente europeu do que para relações internas com os demais países da Europa, onde aparecia em situação de inferioridade. Dentro dessa perspectiva, Portugal explorava as colônias e, ao impor seus valores, trazia de volta elementos culturais dos povos dominados, em face das condições em que se processou esse empreendimento (ABDALA JUNIOR, 2007, p. 68).
}

O conflito das influências é inevitável, uma vez que as relações político-culturais entre Brasil, Portugal e África construíram boa parte da História mundial, pois o comércio de escravos foi desastroso para o desenvolvimento da África, de Angola, especificamente, ao passo que foi a base civilizacional do Brasil e a sustentação econômica de Portugal. Se assim não fosse, a presença portuguesa teria sido abreviada. Bosi diz que o

tráfico, mais ativo do que nunca, trouxe aos engenhos e às fazendas cerca de 700 mil africanos entre 1830 e 1850 . As autoridades, apesar de eventuais declarações em 
contrário, faziam vista grossa à pirataria que facultava o transporte de carne humana, formalmente ilegal desde o acordo com a Inglaterra em 1826 e a lei regencial de 7 de novembro de 1831. A última qualificava como livres os africanos aqui aportados dessa data em diante (BOSI, 1992, p. 196).

Diante da constatação histórica, pode-se pensar que a escravidão e o processo de assimilação, mesmo que ilegal, desta mão de obra, levou à manutenção do território em constante situação de mobilidade política e militar, subordinando Angola ao Brasil, numa relação fornecedor/fornecido, porque a "África tornou-se a única fonte capaz de oferecer ao Brasil a gente que necessitava para ocupar seu vasto território, assegurar sua unidade e transformar-se numa grande nação. E o africano apesar de oprimido, humilhado e reduzido em sua humanidade pela escravidão, cumpriu esse papel e deixou sua marca profunda em todos os setores da vida brasileira" (SILVA, 2003, p. 23). Faz-se importante dizer que essa marca ainda nos é muito tênue, uma vez que os brasileiros somos incapazes de dimensionar a importância fundante da cultura negra em nosso país; somos incapazes de perceber a urdidura semântica que nos ergueu como nação.

A rede imaginária que se forma a partir dessas relações históricas entre a metrópole e os colonizados está muito bem representada nas literaturas que vêm com as independências dos países africanos que foram colônias lusitanas e com o reflexo político que se estende a Portugal, após a Revolução dos Cravos: o Brasil oferece uma imagem positiva à África, que se vai opor à representação de Portugal. A imagem que os africanos, mais ainda os angolanos, fazem dos brasileiros é a de um espaço fluído em aproximações culturais, ignorando a cautela de Dom João VI, varrendo oceano e distribuindo cargos emergenciais sob a ameaça de Napoleão, os africanos (des)significam as causas que levaram o Brasil a ganhar a independência décadas antes da sua, o que se fixa é a plasticidade da bem-aventurança e é, pois, pela "imagem que a alma humana representa com maior exatidão ainda as virtudes" (DURAND, 1999, p. 19). A imagem é a do Brasil que tem uma base civilizacional muito próxima e uma formação política oriunda da mesma fonte: a portuguesa. Portugal permanece latente nas organizações sociais brasileiras e os brasileiros estão perpetuados na África, como a África está, no Brasil, solidificada de muitas formas.

É importante evidenciar que as relações Brasil/África/Europa ou mais especificamente Brasil/Angola/Portugal, na política ou na literatura ou na tessitura de suas Histórias, são uma relação de percepções e enleios culturais, antes de qualquer outra impressão, fazendo com que haja um constante diálogo do campo das representações da vida cotidiana que está interpermeado de influências. O que se sedimenta é o diálogo e a confluência de vozes, são as matizes africanas e europeias que os sujeitos lusófonos trazem em si como constituintes de sua referência nacional. O que se evidencia é a poética da mescla das referências, um fazer regional que em sua plenitude multifacética constitui uma realidade universal.

As imagens do Brasil, Portugal e Angola despontam como o instrumento que gera uma força de continuidade. Isso é uma espécie de espaço coerente e produtor de significado da História, pois a imagem "é a representação de uma realidade cultural [...] através da qual o indivíduo ou o grupo que a elabora (ou que a partilha ou que a propaga) revela e traduz o espaço ideológico no qual se situa" (PAGEAUX \& MACHADO, 1981, p. 43). Então, o Eu, o Outro e o Outro-eu-meu que se vai compor, a partir das relações estabelecidas, e que se fixa como o ponto de colmatação, estão relacionados de forma tão ampla e tão intrínseca que passam a existir quase que completamente devido à existência dessa acentuada relação de alteridade. 
Isso é manifesto dentro das organizações dos Estados Modernos - e assim caracterizamos por conta e risco aquelas Nações que se configuraram Estados Nacionais a partir do fato de terem sido colonizadas - em que as identidades surgem já problemáticas desde o ponto de vista das confluências de discursos culturais que irão representá-las, principalmente no período pós-colonização. Peter Burke (2003) discute essa hibridização das relações sociais e das formações dessas organizações antropológicas, a partir do instante do primeiro contato, sistematizando essa existência para que a leitura das inter-relações não seja feita de forma aleatória, ensina o autor que não se pode abordar o hibridismo “indiscriminadamente". Isso está também em Antonio Candido (1985) quando afirma categoricamente que estudar Literatura Brasileira é estudar Literatura Comparada e que não há a possibilidade de produzirmos um arranjo simbólico sem que se produza uma síntese dos estratos simbólicos.

Sendo esse entrelaçamento cultural perceptível, logicamente, pensa-se que isso é possível devido a uma série de necessidades e impressões que vão-e-vêm inseridas em determinada rede imaginária, ou dentro de outra urdidura de significação que se cerze. Consideramos as colocações de Burke nesta discussão porque desejamos chegar às imagens híbridas às quais se refere. Diz ele que na perspectiva da interpretação do mundo isso se mostra, o hibridismo dos estereótipos "está claro na questão das convergências e/ou afinidades entre imagens, ou seja, aquelas que exercem uma função semelhante, embora tenham imagens diferentes" (BURKE, 2003, p. 26), o que significa que o embate cultural dá início a um processo de releitura conceitual e faz emergir demandas outras que não existiriam se não fosse a relação de poder estabelecida.

Pensemos no sincretismo religioso no Brasil com a escravatura e a colonização portuguesa e suas manifestações culturais. Imagens diferentes, funções semelhantes, ou em todas as relações político-culturais que a História registra entre Portugal, Brasil e África. Pensemos no papel fundante das culturas lusitana e negra para nossa identidade nacional, constituindo uma universalidade regional. De tal forma, a questão do sincretismo acentuado se faz plenamente compreensível, no Brasil, porque o escravo africano deslocado e desespacializado vai constituir um estado outro de representações, já que uma "nação é uma comunidade simbólica e é isso que explica seu poder para gerar um sentimento de identidade e lealdade" (HALL, 1999, p. 49), derivando à gestação de um espaço habitável em meio à hostilidade proporcionada pelas esferas da sociedade escravocrata brasileira.

É relevante, ainda, registrar que as administrações brasileiras, historicamente, se posicionaram ao lado dos governos africanos, embora o governo JK, por exemplo, lançasse um olhar indiferente e acovardado para o continente negro, preservando inconteste o alinhamento político e as relações entre Brasil e Portugal, ademais o momento histórico não exigia nenhum tipo de efetiva prática nas relações internacionais com as colônias portuguesas na África, de acordo com Martins (1999). Nas políticas de relações exteriores, quando se fez necessário defender interesses comuns, como em questões de reconhecimento das práticas políticas internas, o Brasil, aproximado da África por sua base civilizacional ou pelo passado comum ou retribuindo a gentileza histórica do reconhecimento da independência em 1822, ergueu-se em favor da África negra.

Dois episódios, dessas relações, foram importantes: o primeiro foi o fundamental apoio dado pelo Brasil às Nações africanas em desenvolvimento, quando elas exigiam a entrada de seus produtos tropicais no mercado comum da Europa, o que, por obviedade, os seis grandes países europeus não aceitavam e pela interferência brasileira cederam a liberação de quotas de exportação para os africanos. O outro foi quando, em 31 de janeiro 
de 1961, em comunicado proferido ao povo brasileiro, no contexto da PEI (política externa independente), através da Voz do Brasil, Jânio Quadros, discursa:

\begin{abstract}
Atravessamos horas das mais conturbadas que a humanidade já conheceu. O colonialismo agoniza, envergonhado de si mesmo, incapaz de salvar os dramas e as contradições que engendrou [...]. Abrimos nossos braços a todos os países do continente. Somos uma comunhão sem prevenções político-filosóficas. Os nossos portos agasalharão todos os que conosco queiram comerciar. Somos uma comunhão sem rancores ou temores. Temos plena consciência da nossa pujança para que no arreceemos de tratar com quem quer que seja" (QUADROS apud RODRIGUES, 1964, p. 374).
\end{abstract}

Generalizando a afirmação, como aí está, e guardadas as devidas particularidades, a História do colonialismo europeu é a História da construção do indivíduo brasileiro e do indivíduo africano. Assim como a História da formação das nações mestiças é a História da Europa, pois "que país europeu foi só e exclusivamente europeu? Alguma vez a Europa foi só Europa?” (RIBEIRO, 2002, p. 387). E, então, dentro de uma conjuntura social tensionada historicamente, o Brasil desponta como um elemento catalisador, uma cultura que, por se haver construído a partir de uma base luso-africana, tem a função de harmonizar relações entre colonizador/colonizado. Para a diplomacia, tanto a brasileira como a portuguesa, o Brasil tinha a missão de ser o mediador entre a Europa e os países tropicais, tendo um papel a cumprir no Atlântico: o de ajudar a reforçar a língua e a cultura portuguesas na África. Daí a ideia, levantada outrora, de criação de uma comunidade atlântica compreendendo o Brasil, o Portugal metropolitano e as nações africanas (SARAIVA, 1996, p. 143).

O que se nota é a existência de uma referência imagético-cultural, a nação que contém em sua construção a essência das possibilidades de diálogo entre os países que ensaiam um reconhecimento não mais como colonizador/colonizado, opressor/oprimido, ou qualquer outra oposição que o valha, mas que vislumbram possibilidades de um (re) arranjamento dialógico, é o Brasil. O mesmo país que permeia, juntamente com Portugal, constantemente a ficção africana, trazendo a possibilidade de representação de uma identidade nacional mestiça, habita também sua História numa ação constituidora de sentido e rompedora do silenciamento beligerante. Isso significa que circunspecto às relações de poder ainda existentes, pois não se pode apagar as feituras de Clio tão facilmente, tem-se emergindo uma outra relação: a do reconhecimento das influências, o que servirá para a elaboração de um outro discurso. O que servirá para a edificação de uma identidade em que o Eu-africano se erguerá da formação discursivo-identitária lusitana e mostrará o que de europeu nele há. Em que o Eu-africano se erguerá da identificação do discurso de reconhecimento do outro-em-si e mostrará o que de brasileiro nele há e o que de africano no brasileiro está evidente, em uma constituição de imagens que oferecem a possibilidade de uma comunicação "trans-histórica” como ensina Eliade (1996, p. 174).

A vazão das influências da África para a Europa e da Europa para o Brasil, notadamente, dá-se na mesma cadência. Desta forma, parece relevante registrar, ainda, que a ossatura das relações do Brasil com a África e com Portugal, está contida na imagem gestada pela palavra. A mesma palavra que atravessava o oceano para trazer o reconhecimento da soberania brasileira pelos africanos, que atravessava o oceano na proa dos navios para comunicar os anseios dos escravos de aqui para suas famílias de lá e que servem, agora, para que se comece uma releitura de nós mesmos, hibridizados que nos construímos, dando conjunções ao nosso imaginário e sonhando um espaço de desejo catalisador de uma imensidão íntima que, por vezes, esteve imersa em desejos e sonhos coletivos. 
ABDALA JUNIOR, B. Literatura, história e política. Cotia: Ateliê Editorial, 2007. ALEGRE, M. Muana Puó: ou talvez o nosso rosto. Jornal de Letras, Artes e Idéias: Lisboa, p.3-4, 29 março/11 abril 1995.

BRAZIL, C.; AZAVEDO, G. Pepetela: pelo amor recíproco entre África e Brasil. Acesso em: http://www.jornalirismo.com.br/literatura/17/1406-pepetela-pelo-amor-reciproco-entre-africa-e-brasil. Acesso em 26 de setembro de 2012.

BACHELARD, G. A poética do espaço. São Paulo: Martins Fontes, 1998.

BARTHES, R. O rumor da língua. São Paulo: Brasiliense, 1985.

BOSI, A. Dialética da colonização. São Paulo: Cia das Letras, 1992.

BHABHA, H. K. O local da cultura. Belo Horizonte: Editora da UFMG, 2007.

BURKE, P. Hibridismo Cultural. São Leopoldo: Unisinos, 2003.

CANDIDO, A. Literatura e sociedade. São Paulo: Nacional, 1985.

CASSIRER, E. Linguagem e mito. São Paulo: Perspectiva, 1975.

CHAVES, R. et alli (Org). Brasil/África: como se o mar fosse mentira. São Paulo:

Editora da Unesp, 2006.

. Angola e Moçambique: experiência colonial e territórios literários. Cotia:

Ateliê Editorial, 2010.

DURAND, G. O imaginário: ensaio acerca das ciências e da filosofia da imagem.

Rio de Janeiro: Difel, 1999.

ELIADE, M. Mito do eterno retorno. São Paulo: Mercuryo, 1992.

Mito e realidade. São Paulo: Perspectiva, 1996.

$\overline{\mathrm{HALL}}, \mathrm{S}$. A identidade cultural na pós-modernidade. Rio de Janeiro: DP\&A, 1999.

KI-ZERBO, J. História da África Negra. Lisboa: Publicações Europa-América, 1972.

LARANJEIRA, P. Ensaios Afro-literários. Coimbra: Novo Imbondeiro, 2001.

LAPLATINE, F. \& TRINDADE, L. O que é imaginário. São Paulo: Brasiliense, 1997.

MARTINS, R. P. A diplomacia da prosperidade: a política externa do governo Cos-

ta e Silva. Dissertação (Mestrado em Ciência Política) - IFCH, Universidade Federal do Rio Grande do Sul, 1999. 160f.

PAGEAUX, D.H \& MACHADO, A.M. Da literatura contemporânea à teoria da

Literatura. Lisboa: Edições 70, 1981.

PEPETELA. Lueji:o nascimento dum império. Lisboa: Dom Quixote, 1989.

. A geração da utopia. Lisboa: Dom Quixote, 1992.

RIBEIRO, Maria Manuela Tavares. A ideia de Europa. Lisboa: Almedina, 2002.

RODRIGUES, J.H. Brasil e África: outro horizonte. Rio de Janeiro: Civilização Brasileira, 1964.

SARAIVA, J. F. S. O lugar da África. Brasília: UNB, 1996.

SHARPE, J. A história vista de baixo. In: BURKE, Peter. (Org.) A escrita da história. Novas perspectivas. São Paulo: Unesp, 1992. p.39-62.

SILVA, A. da C. e. Um rio chamado Atlântico: a África no Brasil e o Brasil na África. Rio de Janeiro: Nova Fronteira, 2003. 